\title{
Human Platelet Alloantigens (HPA-3) Polymorphism in Sickle Cell Disease Patients with Vaso-Occlusive Crisis
}

\author{
IMAN R. EL-MAHGOUB, M.D.*; AZZA A. ALI, M.D.**; AMIRA S.A. FARHAN, M.Sc.**; \\ MONA K. EL-GHAMRAWY, M.D.***; HEBATULLLA FAROUK, M.D.***; SOHA ATEF, M.D.**; \\ GEHAN H. SHAHIN, M.D.* and RANIA SOLIMAN, M.Sc.** \\ The Department of Clinical \& Chemical Pathology, Faculty of Medicine Cairo University*, National Research Centre** and \\ Pediatric Department, Faculty of Medicine Cairo University***
}

\begin{abstract}
Background: Vaso-occlusive crisis (VOC) is a significant cause of morbidity and mortality in sickle cell disease (SCD) patients. As polymorphisms in human platelet antigens (HPA) exhibit a prothrombotic nature, we hypothesized that specific HPA polymorphisms could have a role in the pathogenesis of VOC in SCD.
\end{abstract}

Aim of Study: This study investigated HPA-3 T2622G among Egyptian SCD patients.

Patients and Methods: This study included 100 SCD patients and 50 controls. Patients were divided into, VOC group $(n=60)$, and steady-state group $(n=40)$. Genotyping was done using PCR-based Restriction Fragment Length Polymorphism (RFLP) technique.

Results: The HPA-3 mutant genotypes were significantly associated with SCD compared to controls $(p=0.001)$, while no significant difference was observed between VOC and steady-state groups $(p=0.169)$. Regarding the frequency of VOC episodes, the HPA-3 homozygous mutant genotypes showed significant differences ( $p=0.001)$. The HPA-3 mutant genotypes were significantly correlated with generalized type of VOC ( $p=0.006)$ and need for hospitalization $(p=0.003)$. Regarding VOC complications, the HPA-3b/3b genotype was significantly associated with acute chest syndrome $(p=0.008)$ and stroke $(p=0.012)$.

Conclusion: The HPA-3 T2622G is common among SCD patients. Although it is not a major determinant of vasculocclusion in SCD, it is significantly associated with VOC complications and may alter their outcome.

Key Words: Sickle cell disease - Vaso-occlusive crisis - HPA - PCR-RFLP.

\section{Introduction}

SICKLE cell disease (SCD) is an inherited disorder caused by a single point mutation (GTG $>\mathrm{GAG})$ in the sixth codon of the $\beta$-globin gene, producing

Correspondence to: Dr. Iman R. El-Mahgoub,

The Department of Clinical \& Chemical Pathology,

Faculty of Medicine Cairo University hemoglobin $\mathrm{S}(\mathrm{HbS})$ [1] . HbS polymerization changes the morphology and life span of the red blood cell, causing vaso-occlusive crisis (VOC), which is a sign of SCD [2]. VOC results from an interaction between the red sickle cell and the endothelium, enhancing cellular adhesion to the vascular endothelium and causing activation of the endothelial cells of the vessels and chronic inflammation [3]. Heterocellular aggregation results from the adhesion of both red and white blood cells to the vessel wall, followed by the trapping of erythrocytes and a reduction in blood flow, followed in turn by microcirculation occlusion [4] .

Although a large proportion of sickle cell phenotypes have been assigned to variable risk factors [5], there are interindividual variations due to genetic variations in platelet receptors and coagulation factors [6], which supports the notion that prothrombotic polymorphisms influence SCD phenotype. They regulate primary hemostasis via the maintenance of vascular integrity and the repair of wounds. Platelets play an important role in the prevention of blood loss at sites of injury, and disturbances in the activity of platelets lead to thrombotic or hemorrhagic disorders [7].

Platelet activation is mediated by human platelet alloantigens (HPAs), a combination of platelet membrane glycoprotein (Gp) and different cellbound factors. More than 19 HPAs have been identified [8]; HPA (1-5) are the most important [9]. Eleven HPAs are on integrin $\alpha \mathrm{II} \beta 3$ (GPIIb/IIIa), and of remaining eight, three are on GPIb/IX/V, two on integrin $\mathrm{a} 2 \mathrm{~b} 1$, and one each on GPIV, GPV, and CD 109 [10]. It has been suggested that genetic polymorphisms due to single base-pair substitutions and single amino acid replacements in HPA-1 
(T196C, Leu33Pro), HPA-2 (T524C, Met145Thr), HPA-3 (T2622G, Ile843Ser), HPA-4 (G526A, Arg143Glu), and HPA-5 (G1648A, Glu505Lys) cause the prothrombotic state, by changing the structure of the platelets and/or the expression levels of the adhesion proteins expression levels. These polymorphisms are accompanied by structural changes [11] and increased expression of the high affinity receptors of collagen, which subsequently changes the binding of other factors [12] It has been demonstrated that HPA polymorphisms play a prothrombotic role [13], and they have been associated with hypercoagulable states and disorders of thrombosis [14], such as ischemic stroke [15], fetal loss, and ischemic heart and cerebrovascular diseases specifically in SCD patients [16]

In this study, we inspected the association of HPA polymorphic variants with VOC, which allows for the identification of SCD patients at high risk for developing VOC. We assumed that VOC is accompanied by specific HPA polymorphic variants. We investigated the distribution of HPA-3 and HPA-5 alleles among SCD patients (with and without VOC) using the polymerase chain reactionrestriction fragment length polymorphism (PCRRFLP) technique.

\section{Subjects and Methods}

This retrospective case control study comprised a total of 100 SCD patients (66 of them were SS and 34 were $S \beta$ ) diagnosed and followed up at the Hematology Outpatient Clinic, New Children Hospital, Cairo University from February 2014 to February 2015 and 50 healthy unrelated age and sex matched subjects as control group. Diagnosis of SCD was based on clinical presentation, haematological indices and haemoglobin electrophoresis. The study protocol was approved by the Research Ethics Committee of Cairo University. Informed consents were obtained willingly from all subjects and/or their guardians before enrolment in the study.

SCD patients were assigned to one of two groups: Patients who had at least single VOC event during the previous 9 months. (VOC group; $n=$ 60 ), or those who reported no such events over the last 9 months (Steady-state group; $\mathrm{n}=40$ ).

VOC group included 33 (55\%) males and 27 (45\%) females. Their ages ranged between 2 and 27 years with mean age of 11.8 years. Steady-state group included $19(47.5 \%)$ males and $21(52.5 \%)$ females with a mean age of 11 years (range 1.529 years). Control group comprised $30(60 \%)$ males and $20(40 \%)$ females, their ages ranged between 2 and 25 years with mean age of 15 years.

For all included patients, review of medical records, detailed history-taking by direct interview and thorough clinical examination were performed. Laboratory investigations for all enrolled subjects included complete blood picture using automated cell counter (Cell Dyn-1700), Leishman stained peripheral blood film examination, reticulocytic count, hemoglobin electrophoresis and genotyping of T2622G SNP of HPA-3 gene by Polymerase Chain Reaction-Restriction Fragment Length Polymorphism (PCR-RFLP) analysis.

\section{DNA extraction and genotyping:}

Genomic DNA extraction from whole blood was done using Gene JET Genomic DNA purification kit (Cat. \#K0721 \#KO72, Fermentas Life Sciences), following the manufacturer's instructions. DNA samples were routinely stored at $20^{\circ} \mathrm{C}$. Amplification of extracted DNA for detection of T2622G SNP of HPA-3 gene was performed using PCR technique. We used primers for amplification of T2622G mutation of HPA-3 gene as described by Hurd et al. [17]. Primers were provided by "The Midland Certified Reagent Co".

- For T2622G SNP of HPA-3 gene:

- Forward primer (5'-CTCAAGGTAAGAGCTGTGAAGAAGAC-3')

\section{- Reverse primer (5'-CTCACTACGAGAAGGAT CCTGAACCTC-3')}

Visualization of the amplified PCR products was performed using agarose gel electrophoresis and ultra-violet light trans-illumination. DNAethidium bromide complexes absorb ultra-violet light at 260,300 or $360 \mathrm{~nm}$ and emit at $590 \mathrm{~nm}$ in the red orange region of the visible spectrum. PCR amplification of DNA fragment carrying T2622G SNP of HPA-3 gene gave a band of 747bp.

Digestion of the amplified products was performed by specific restriction enzyme. For the HPA-3 gene polymorphism, fokI restriction enzyme (supplied from Thermo Scientific, Code no. \#FD2144) was used (Fig. 1A).

The HPA-3 T2622G polymorphism is caused by an amino acid substitution of iso-leucine 843 by serine (Ile843Ser) due to $\mathrm{T} \rightarrow \mathrm{G}$ substitution at 2622 position in the coding region of HPA-3 gene. The presence of isoleucine (a allele) at locus 843 within the coding region of HPA-3gene (wild type allele) produced restriction fragments of 108, 149 and $191 \mathrm{bp}$ whereas the presence of serine ( $\mathrm{b}$ allele) 
generated mutant allele that produce restriction fragments of 149 and 299bp after fokI digestion [17].

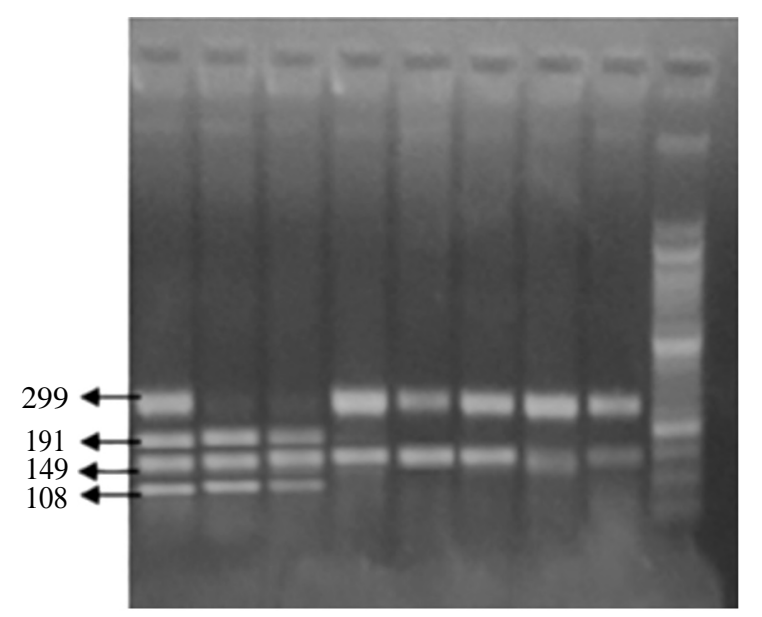

Fig. (1): Agarose gel electrophoresis of PCR fragments digested by restriction enzymes. HPA-3 system (FokI endonuclease): Allele a=Fragments of 108, 149, 191bp; allele $\mathrm{b}=$ Fragments of 149 and $299 \mathrm{bp}$.

The subjects were considered as:

- Normal HPA-3 (wild type, a/a) genotype if 3 bands are detected at 108, 149 and 191bp.

- Homozygous for $b$ allele (b/b) homo-mutant genotype if 2 bands are detected at 149 and $299 \mathrm{bp}$.

- Heterozygous for $b$ allele $(a / b)$ hetero-mutant genotype if 4 bands are detected at 108,149,191 and $299 \mathrm{bp}$.

\section{Statistical methods:}

Data were analyzed using IBM SPSS advanced statistics version 20 (SPSS Inc., Chicago, IL). Mean, standard deviation, median and range were done for numerical data. Frequency and percentage were done for qualitative data. The relation between qualitative variables was done using Chi-square test or Fisher's exact test. Comparison between the two groups was done using Student $t$-test for quantitative data. Kruskal-Wallis test (non-parametric ANOVA) was used for not normally distributed quantitative data to compare between 3 groups. Risk estimation was done using Odds ratio (OR) with $95 \%$ confidence interval (CI) using logistic regression. All tests were two-tailed. A $p$-value $<0.05$ was considered significant.

\section{Results}

The frequency of the studied genotypes among SCD patients and normal controls are presented in Table (1). The HPA-3 mutant genotypes are significantly more frequent among Sickle celldiseased patients than normal controls $(p=0.001)$. The genotyping of HPA-3 T2622G polymorphism revealed no statistical significant differences between VOC and steady-state patient groups $(p=0.169)$ as shown in Table (2).

On studying the association between frequency of VOC episodes among VOC group of SCD patients and HPA-3 variant genotypes, taking the wild-type HPA-3a/3a as reference, Univariate analysis identified homozygous HPA- 3 b/b to be independently associated with more vaso-occlusive episodes $(p=0.001)$ while heterozygous HPA-3 $\mathrm{a} / \mathrm{b}$ showed no statistical significance $(p=0.185)$ (Table 3).

We also found that HPA-3 mutant genotypes were significantly correlated with generalized type of VOC $(p=0.006)$ and need for hospitalization $(p=0.003)$.

Regarding the complications of VOC, including acute chest syndrome (ACS), stroke and avascular necrosis (AN), the HPA-3 homo-mutant genotype was significantly associated with ACS and Stroke ( $p=0.024$ and $p=0.036$, respectively) as shown in Table (4).

Table (1): The frequency of the studied genotypes among SCD patients and normal controls.

\begin{tabular}{|c|c|c|c|c|}
\hline Genotype & $\begin{array}{c}\text { SCD } \\
(n=100) \\
N(\%)\end{array}$ & $\begin{array}{l}\text { Normal control } \\
\qquad \begin{array}{c}(\mathrm{n}=50) \\
\mathrm{N}(\%)\end{array}\end{array}$ & $p$-value & OR \\
\hline $\begin{array}{l}\text { HPA-3 a/a } \\
\text { (Wild type) }\end{array}$ & $22(22)$ & 49 (98) & $* 0.001$ & 69 \\
\hline $\begin{array}{l}\text { HPA-3 a/b } \\
\text { (Hetero-mutant) }\end{array}$ & $46(46)$ & $1 \quad(2)$ & & \\
\hline $\begin{array}{l}\text { HPA-3 b/b } \\
\text { (Homo-mutant) }\end{array}$ & $32(32)$ & $0 \quad(0)$ & & \\
\hline
\end{tabular}

* Significant $p$-value.

Table (2): The frequency of HPA-3 genotypes in VOC and steady-state patient groups.

\begin{tabular}{lccc}
\hline Genotype & $\begin{array}{c}\text { VOC } \\
(\mathrm{n}=60)\end{array}$ & $\begin{array}{c}\text { Steady-state } \\
(\mathrm{n}=40)\end{array}$ & $p$-value \\
$\mathrm{N}(\%)$ & $\mathrm{N}(\%)$ & \\
\hline $\begin{array}{c}\text { HPA-3 a/a } \\
(\text { Wild type })\end{array}$ & $15(25.0)$ & $7(17.5)$ & 0.169 \\
$\begin{array}{c}\text { HPA-3 a/b } \\
(\text { Hetero-mutant })\end{array}$ & $23(38.3)$ & $23(57.5)$ & \\
$\begin{array}{c}\text { HPA-3 b/b } \\
\text { (Homo-mutant) }\end{array}$ & $22(36.7)$ & $10(25.0)$ & \\
\hline
\end{tabular}


Table (3): Association of HPA-3 variant genotypes with frequency of VOC episodes in VOC group.

\begin{tabular}{llccc}
\hline \multirow{2}{*}{ Variable } & $\begin{array}{c}\text { Genotype frequency } \\
\text { N }(\%)\end{array}$ & $\begin{array}{c}\text { Frequency of episodes } \\
\text { Mean } \pm \text { SD }\end{array}$ & $p$-value \\
& Wild type & $15(25)$ & $2 \pm 1.1$ & $* 0.001$ \\
HPA-3 & Womo-mutant genotype & $22(36.7)$ & $4 \pm 1.3$ & 0.185 \\
& Hetero-mutant genotype & $15(25)$ & $2 \pm 1.1$ & $* 0.003$ \\
\hline
\end{tabular}

* Significant $p$-value.

Table (4): Association of HPA-3 variant genotypes with VOC complications in VOC group.

\begin{tabular}{|c|c|c|c|c|c|c|c|c|}
\hline \multicolumn{2}{|l|}{ Variable } & \multirow{2}{*}{$\begin{array}{l}\text { Genotype frequency } \\
\text { N (\%) } \\
15(25)\end{array}$} & \multirow{2}{*}{$\begin{array}{l}\text { ACS } \\
\mathrm{N}(\%) \\
1(1.6)\end{array}$} & \multirow{2}{*}{$\begin{array}{r}p \text {-value } \\
* 0.024\end{array}$} & $\begin{array}{l}\text { Stroke } \\
\mathrm{N}(\%) \\
\end{array}$ & \multirow{3}{*}{$\frac{p \text {-value }}{* 0.036}$} & \multirow{3}{*}{$\begin{array}{l}\text { AVN } \\
N(\%) \\
2(3.3) \\
8(13.3)\end{array}$} & \multirow{3}{*}{$\frac{p \text {-value }}{0.363}$} \\
\hline \multirow{6}{*}{ HPA-3 } & Wild type & & & & & & & \\
\hline & Homo-mutant genotype & $22(36.7)$ & $11(18.3)$ & & $8(13.3)$ & & & \\
\hline & Wild type & $15(25)$ & $1(1.6)$ & 0.324 & $\mathrm{O}(0)$ & 0.414 & $2(3.3)$ & 1.00 \\
\hline & Hetero-mutant genotype & $23(38.3)$ & $7(11.6)$ & & $4(6.6)$ & & $5(8.3)$ & \\
\hline & Wild type & $15(25)$ & $1(1.6)$ & $* 0.016$ & $0(0)$ & $* 0.025$ & $2(3.3)$ & 0.228 \\
\hline & Mutant genotypes & $45(75)$ & $18(30)$ & & $12(20)$ & & $13(21.6)$ & \\
\hline
\end{tabular}

* Significant $p$-value. ACS: Acute chest syndrome. AVN: Avascular necrosis.

\section{Discussion}

Previous studies of genes that modify the pathogenesis of vascular occlusion in SCD have identified mutations in prothrombotic genes (HPA, MTHFR-C677T, Factor V leiden-G1691A, ProthrombinG20210A), which may influence vascular occlusion in SCD. The interaction of these genetic mutations may have the synergistic effect of increasing VOC. Knowledge of the mutation prevalence of these genes would ensure preventive treatment for VOC. There is evidence of thrombosis caused by platelet hyperactivity in SCD patients who are genetically predisposed for hyperaggregability [18] .

Below, we report the distribution and influence of T2622G of the HPA-3 gene variants on vascular occlusion in SCD patients using the PCR-RFLP technique.

We observed a significantly higher frequency of HPA-3/T2622G polymorphic variants (HPA$3 \mathrm{a} / 3 \mathrm{~b}$ and HPA-3b/3b) among SCD patients versus control subjects ( $p=0.001$ and 0.003 , respectively). In consistency with our results, a study by Hagous SA and her colleague showed statistical significant difference between SCD cases and controls for HPA-3/T2622G polymorphic variants (HPA-3a/3b and HPA-3b/3b) $(p=0.029$ and $p=0.03$, respectively $)$ [19]. However, Driss et al., found no significant differences in the HPA alleles and genotype frequencies in SCD versus healthy controls [20]

In our study, a comparison of HPA-3 genotype frequencies between VOC and steady-state groups of SCD patients failed to show statistical significance ( $p=0.169)$. This can be attributed to a higher level of $\mathrm{HbF}$ in the steady-state patient groups, which is known to alleviate vascular complications in SCD patients under hydroxyurea treatment, and this may refute the effect of the studied polymorphism [21]. Another study showed a significant difference in the prevalence of HPA-3 polymorphisms between Bahranian SCD patients with VOC and those without it [22].

Nevertheless, in a comparison of the HPA-3 allelic genotypes among the SCD patients with VOC taking the wild-type HPA-3a/3a as references, univariate analysis determined that homozygous HPA-3b/3b is independently associated with more frequent VOC episodes ( $p=0.001)$, whereas heterozygous forms exhibited no statistical significance $(p=0.185)$. Patients with mutant HPA-3 genotypes (homozygous or heterozygous) had significantly more frequent VOC episodes $(p=0.003)$. This is in agreement with a study [22] that demonstrated a significant association of HPA-3a/3b and HPA$3 \mathrm{~b} / 3 \mathrm{~b}$ genotypes with VOC in SCD patients. Our findings indicate that the homozygosity of alleles 
$3 \mathrm{~b}$ can be considered genetic variants that increase the frequency of VOC and the probability of prothrombotic activity in SCD patients.

The present work revealed a significant correlation between HPA-3 mutant genotypes and the type of VOC (generalized vs localized) $(p=0.006)$ and also the need for hospitalization $(p=0.003)$, which is in agreement with El-Subaie et al., results.

Regarding the complications of VOC, including acute chest syndrome (ACS), stroke and avascular necrosis (AN), the HPA-3 homo-mutant genotype was significantly associated with ACS and Stroke ( $p=0.024$ and $p=0.036$, respectively).

Accordingly, the studied polymorphism of HPA3 may influence the course of the disease.

In Conclusion: $\mathrm{T} 2622 \mathrm{G}$ polymorphism of the HPA-3 gene are common among Egyptian SCD patients. The association of HPA-3 mutant genotypes with a higher frequency of VOC episodes and their complications, in addition to the association of HPA-3 mutant genotypes with generalized vaso-occlusion and the need for hospitalization during VOC indicate that the genetic polymorphism can be considered genetic variant that increase the risk of frequent VOC episodes and influence the crises' outcome.

\section{References}

1- INGRAM V.M.: Abnormal human haemoglobins. I. The comparison of normal human and sickle-cell haemoglobins by "fingerprinting". Biochim. Biophys. Acta., June, 28 (3): 539-545, 1958.

2- FIELD J.J., KNIGHT-PERRY J.E. and DEBAUN M.R.: Acute pain in children and adults with sickle cell disease: Management in the absence of evidence-based guidelines. Curr. Opin. Hematol., 16: 173-178, 2009.

3- LANARO C., FRANCO-PENTEADO C.F., ALBUQUEQUE D.M., SAAD S.T., CONRAN N. and COSTA F.F.: Altered levels of cytokines and inflammatory mediators in plasma and leukocytes of sickle cell anemia patients and effects of hydroxyurea therapy. J. Leukoc. Biol., 85: 235-242, 2009.

4- KAUL D.K., FINNEGAN E. and BARABINO G.A. Sickle red cell-endothelium interactions. Microcirculation, 16: 97-111, 2009.

5- BUCHANAN G.R., DeBAUN M.R., QUINN C.T. and STEINBERG M.H.: Sickle Cell Disease. Hematology (Am. Soc. Hematol. Educ. Program), 1: 35-47, 2004.

6- SEBASTIANI P., RAMONI M.F., NOLAN V., BALDWIN C.T. and STEINBERG M.H.: Genetic dissection and prognostic modeling of overt stroke in sickle cell anemia. Nat. Genet, 37: 435-440, 2005.

7- WEYRICH A.S. and ZIMMERMAN G.A.: Platelets: Signaling cells in the immune continuum. Trends Immunol., 25: 489-495, 2004.
8- SANTOSO S.: Human platelet alloantigens. Transfus Apher Sci., 28: 227-36, 2003.

9- KUNICKI T.J.: The influence of platelet collagen receptor polymorphisms in hemostasis and thrombotic disease. Arterioscler Thromb. Vasc. Bio., 22: 14-20, 2002.

10- DECKMYN H., ULRICHTS H., VAN De WALLE G. and VANHOORELBEKE K.: Platelet antigens and their function. Vox. Sang., 87: 105-111, 2004.

11- Calvete J.J.: Platelet integrin GPIIb/IIa: Structure-function correlations. An update and lessons from other integrins. Proc. Soc. Exp. Biol. Med., 222: 29-38, 1999.

12- ULRICHTS H., VANHOORELBEKE K., CAUWENBERGHS S. and VAUTERIN S.: Von Willebrand factor but not a-thrombin binding to platelet glycoprotein Iba is influenced by the HPA-2 polymorphism. Arterioscler Thromb. Vasc. Biol., 23: 1302-1307, 2003.

13- BRAY P.F.: Platelet glycoprotein polymorphisms as risk factors for thrombosis. Curr. Opin. Hematol., 7: 284-289, 2000.

14- CASTRO V., ALBERTO F.L., COSTA R.N. and LEPIKSON-NETO J.: Polymorphism of the human platelet antigen-5 system is a risk factor for occlusive vascular complications in patients with sickle cell anemia. Vox. Sang., 87: 118-123, 2004.

15- BAKER R.I., EIKELBOOM J., LOFTHOUSE E., STAPLES N., AFSHAR-KHARGHAN V., LÓPEZ J.A., SHEN Y., BERNDT M.C. and HANKEY G.: Platelet glycoprotein Iba Kozak polymorphism is associated with an increased risk of ischemic stroke. Blood, 98: 36-40, 2001.

16- GERHARDT A., SCHARF R.E., MIKAT-DROZDZYNSKI B. and KRUSSEL J.S.: The polymorphism of platelet membrane integrin a2b1 (a2807TT) is associated with premature onset of fetal loss. Thromb. Haemost., 93: 124129,2005 .

17- HURD C.M., CAVANAGH G., SCHUH A., OUWEHAND W.H. and METCALFE P.: Genotyping for plateletspecific antigens: Techniques for the detection of single nucleotide polymorphisms. Vox. Sang., 83: 1-12, 2002.

18- SINGER S.T. and ATAGA K.I.: Hypercoagulability in sickle cell diseaseand beta-thalassemia.Curr. Mol. Med., 8: 639-45, 2008.

19- HAGOUS S.A. and IBRAHIM I.K.: Platelet glycoprotein IIb polymorphism and platelet indices in Sudanese patients with Sickle Cell anemia. European Journal of Biomedical and Pharmaceutical Science, 3 (6): 18-22, 2016.

20- DRISS A., KACEM K., WILSON N., HIBBERT J., ADAMKIEWICZ T., GEE B.E., MEDDEB B. and STILES J.K.: Human Platelet Alloantigens (HPA)1, HPA2 and HPA3 SNPs in Tunisian Sickle Cell Disease Patients. Blood, 118: 4852, 2011.

21- OFORI-ACQUAH S.F., LALLOZ M.R., SERJEANT G and LAYTON D.M.: Dominant influence of gammaglobin promoter polymorphisms on fetal haemoglobin expression in sickle cell disease. Cellular and Molecular Biology, 50: 35-42, 2004.

22- AL-SUBAIE A.M., AL-ABSI I.K., AL-OLA K., SAIDI S., FAWAZ N.A. and ALMAWI W.Y. (2009): Gene frequencies of human platelet alloantigens in Bahraini Arabs. Am. J. Hematol., 82: 242-4, 2007. 


\section{تأثير تعلد الشكل الجينى لجينات HPA3 في مرضى الأنيميا المنجلية

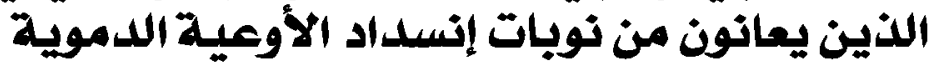

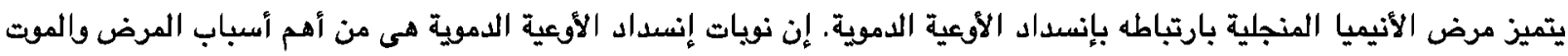

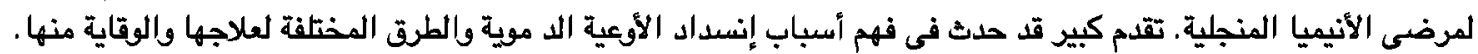

مصل الصفائح البشرية يتسبب فى تنشيط وإلتصاق الصفائح، هو مركب من البروتين السكرى مع عدة عوامل أخرى ملزمة الخلية. لأن تعدد النمط الجينى لمصل الصفائح البشرية يرتبط بزيادة فى القابلية اللتجلط، إفترضنا فى هذا البحث أن تعدد النمط الجينى لمصل الصفائح البشرية قد يكن مرتبط بنوبات إنسداد الأوعية الدموية في مرضى الهئ الأنيميا المنجلية.

على حدوث نويات، HPA-3 الهدف من هذا البحث تقييم تأثير تعدد النمط الجينى لمصل الصفائح البشرية إنسداد الأوعية الدموية فى المئ مرضى الأنيميا المنجلية. وهذا بإستخدام تفاعل البلمرة المتسلسل وتبعه تقييد طول القطعة البعل المتعددة الأشكال.

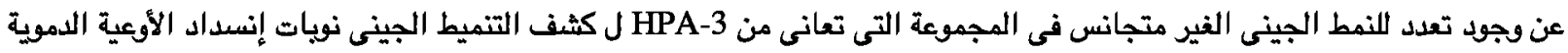

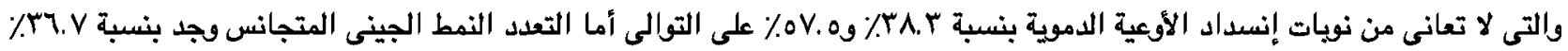

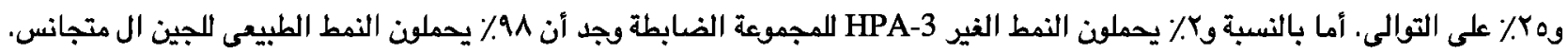

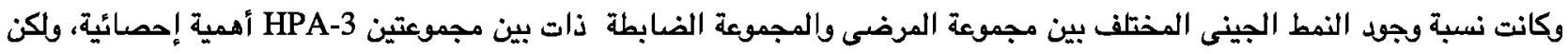
مقارنة نسبة وجود النمط الجينى المختلف للجين ال المرضى لم تكن ذات أهمية إحصائية.

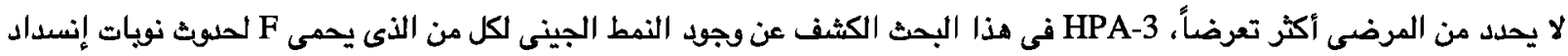

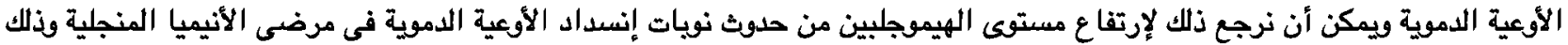

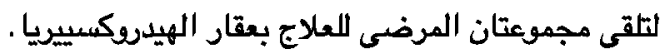

